\title{
Agricultural Land Use Change under Migration Context: An Evidence from a Vietnamese Village
}

\author{
Thi Minh Khue Nguyen ${ }^{1,2}$, Thi Dien Nguyen ${ }^{1} \&$ Philippe Lebailly $^{2}$ \\ ${ }^{1}$ Faculty of Political and Social Sciences, Vietnam National University of Agriculture, Trau Quy. Gia Lam, Hanoi \\ 131000 , Vietnam \\ ${ }^{2}$ Faculty of Economic and Rural Development, Gembloux Agro-Bio Tech - ULiège, Passage des Déportés, 2 \\ B-5030 Gembloux, Belgium \\ Correspondence: Thi Minh Khue Nguyen, Faculty of Political and Social Sciences, Vietnam National University \\ of Agriculture, Trau Quy. Gia Lam, Hanoi, 131000 Vietnam. Tel: 84-9-4880-8358. E-mail: \\ nguyenthiminhkhue@student.uliege.be
}

Received: May 12, 2019

Accepted: June 28, 2019 Online Published: July 12, 2019

doi:10.5539/jsd.v12n4p28

URL: https://doi.org/10.5539/jsd.v12n4p28

\begin{abstract}
Migration has no doubt been a crucial factor in contribution to national economic growth and development in rural areas. However, it impacts on agriculture and agricultural land keeps debate. Unlike the prediction of land abandon and de-agrarianization, evidence from a Vietnamese village shows that majority of rural households keep their paddy field and continue their agricultural production rather than converted it into other purposes. While none households in the village absolutely leave their farming land fallowed, there were some households partially abandon their land. Possessing to land is more for investment than agricultural production. Agricultural land and farm work are always a stable resource, a guarantee of subsistence or a safety net for rural people which would boosting their own autonomy.
\end{abstract}

Keywords: migration, land use, peasants autonomy, de-agrarianization, livelihood

\section{Introduction}

Vietnam still tends to be characterized as a region where farming remains the pre-eminent occupation. Indeed, statistics shows that even Vietnam has recently experienced rapid industrialization and modernization which would lead to the diminishing role of agriculture (Bui Minh 2012, Hoang Xuan Thanh et al. 2013). There has been a change in the structure of GDP whereby the share of agriculture has relative declined from 42 percent in 1989 to 26 percent in 1999 and 21 percent in 2011 while the industry sector has more than doubled from 23 percent in 1990 to 47 percent in 2011 (GSO 2011). Despite the prediction of de-agrarianisation, agriculture is enduring (Hirsch 2011, Peemans 2013). The economy of Vietnam sill depends on agriculture which accounts for more than one-quarter of the GDP, provides $85 \%$ of exports and employs about $60 \%$ of the work force, and a large part of the Vietnamese population (68\%) resides in rural areas which makes farming continue to be the important lives and livelihoods of many Vietnamese, especially the most vulnerable people. Besides, Vietnam's agricultural sector is characterized by small household producers with $70 \%$ of households have less than 0.5 hectares in 2011 and the share of the largest category of holdings - above 2 hectares constitutes only slightly 6 percent. Therefore Vietnamese agriculture faced significant constraints on production, which is exactly the setting in which migration could have effects on agricultural production.

Agricultural land has been converted toward more market and industrial orientation to gain faster economic development (Nguyen Thi Minh Khue, Nguyen Thi Dien, and Ph. 2016a, Nguyen Thu Phuong et al. 2008). Therefore, since late 1990s Vietnam witnessed a significant increase of off-farm business ever. Rural households often adopt more than one strategy and become increasingly dependent on the off-farm and delocalized activities of their migrant members to sustain their livelihood (Nguyen Thi Dien, Lebailly, and Vu 2014). Rural households have become increasingly dependent on the off-farm and delocalized activities of their migrant members to sustain their livelihoods. Rural out migration on one hand is manifest to have been an integral component of the sustainable urbanization and national economic transition (Anh 2008, Coxhead, Nguyen, and Linh 2015). On the other hand, the impacts out-migration have had a complex and multiple dimensions on agriculture at the village level (Bui Minh 2012, de Brauw 2010). In reality, relations between migration and agricultural production, 
household livelihoods and community development are more mixed and heterogeneous than either the optimistic or pessimistic views suggest. This paper tries to unveil the different pathways in which migration effects on the agricultural land as the most important productive resource in agriculture. In other words, this paper analyzed the way rural household manage their land used purposed and land holdings in cultivation while at the same time participating in migration and other livelihood diversification. The methodology is discussed in the coming part while the main result and discussions are presented in the third section, following by the conclusion.

\section{Research site and Methodology}

The fieldwork was conducted in 2015 in Maithon Village in Chi Lăng Commune, Que Vo District, Bacninh Province in Vietnam. "Làng" (village) was one of the most typical institutions of ancient Vietnamese society (Dũng, 2010; Gourou, 1945). Paul Mus (1952: 240) stated that "Vietnam is a network of villages" and he emphasized "it was villages that produced Vietnam and it was in them that one learned to apprehend it, at decisive times, in its national spirit" (Mus, 1952:21). Every village had its own lands, agricultural practices, its own property and its own justice, with distinct traditions, cultures, politics and economics (Khoang, 1966) Therefore, a village has been viewed as the most appropriate entry point for research into rural conditions and change in rural Asian and particularly in Vietnam studies. In this thesis, I choose Maithon as one typical Vietnamese village of Bac Ninh province in Red River Delta of Vietnam to do research. Bac Ninh is located in Red River Delta, about 30km far north from the capital Ha Noi, along the recently upgraded National Highway 1A. Red River Delta region of Vietnam shares the common features of agrarian transition undergone by the Doimoi Reform. Agricultural land has been converted toward more market and industrial orientation to gain faster economic development. According to the recent National Survey on Land, in a decade from 2000 to 2010, the non-agricultural land increased 89000 hectares while the land for rice production decreased more than 34000 hectares annually (Nguyễn Ngọc Công, 2012). The overall number of landless farmer households in the region was 3.3 percent in 1999, 13.9 percent in 2002 rose up to 22 percent 2012 (FAO, 2014). Red River Delta historically is also the densest populated region in Vietnam with average 0.04 hectares per head (Note 1). Therefore, since late 1990s this region witnessed a significant increase of off-farm business ever. Rural households often adopt more than one strategy to diversify their livelihood such as intensifying agricultural production and diversifying their economic activities in non-farm business. It is noteworthy that this area have a good infrastructure and transport link allows people to seek employment in the capital Hanoi and other local urban centers without the need of leaving their hometown permanent.

Sharing the same characteristic with other villages in Red River Delta, Maithon was chosen because firstly this village has experienced dramatically change due to modernization process of Doimoi, in which the high level of migration is one of fundamental characteristics (Rigg \& Vandergeest 2012). Secondly, Maithon socio-economic conditions are characterized by monoculture in rice production and before its first high wave of temporary migration in 2005, the village population was mainly leaned on farming as the only source of income. Until now, it is considered as the lowest on economy status due to having no industrial zone, no traditional handicraft as other villages, and very limited dynamic non-farm business diversification and at far distance from capital of province $(30 \mathrm{~km})$. Thanks to its mono-source of earnings in rice production, the Maithon household income in 2005 could be recalled based on their agricultural land areas which had statistics record. Besides, monoculture gives me a chance to isolate the impact of circular migration with the rural areas from other factors.

In this dissertation, I use both qualitative and quantitative data. The qualitative data come from two sources. The first source is published and unpublished data of the agricultural land, the village, and the commune. The second source is observations, interviews and conversations during fieldwork. The quantitative data come from the survey which were carried out in 2015. In addition, I also use population statistics and socio-economic data provided by the commune, particularly those related to land use and labour. Overall, Mai Thon village has 158 households (up to July/2015) which include 699 villagers. I did interview with 128 households, equivalent with $81 \%$ of the whole village household number. There are still 30 households that I could not make interviews. These cases are households who are long-term migrating or they are only too small children who cannot be interviewed. However, I still collect the general information of these household from Hokhau (Note 2) book (which is updated to 9/2014). The systematic survey divided 128 households in the village into four groups, detailed as below:

Group 1: includes the households whose family member(s) participated out of village and short-distance migration which permit them commuting daily during the last 12 months. There were 42 households in this group.

Group 2: Migration households: family member(s) only migrate for work out of province, and normally is long-distance during the last 12 months. This type of migration is much diversified, including both national and 
international migration, seasonal and long-term migration. There were 23 households in this groups. In fact, 30 inacessible households were belonged to this groups however I could not conduct the information from them.

Group 3: Mixed migration households: family members participated in both types of short-distance and long-distance migration during the last 12 months. There were 42 households in this group

Group 4: Non-migration households: none of family member participated in any types of migration during the last 12 months. At the time 2015, there were 21 households which all of their members stayed in the village, and conducted no migrating activities. However, among these 21 households, there were 6 households which fell into the sick and/or the alone elder cases, in other words, they were considered as incapable of working, living under the poverty line and totally leaning on the social allowance. Thus, I abstracted these number of households out of this categories and the total households in this group was only 15 left.

The systematic questionnaire investigation and participatory observation were to provide a broader picture, while the in-depth interviews and biographies were specifically directed to provoke a profound illustration of the peasant's daily life, their perceptions related to agricultural land issued.

\section{Findings and Discussions}

\subsection{Overview of agricultural land in Mai Thon village}

Agrarian studies on rural transformation reveal that one of the factors leading farmers to move away from agriculture is the diminishing importance of agricultural land (Li 2011; Vandergeest 2012). Recently many scholars argued that rural livelihoods should no longer be considered as being directly tied to agriculture and land issues (Rigg 2005, Vaddhanaphuti and Wittayapak 2011). It becomes increasingly popular for rural households to be less engaged in agriculture than ever before and as the result land would be isolated from agriculture which have been observed in Thailand (Rigg and Nattapoolwat 2001), in Philippines (McKay 2005). As a consequence of receiving remittances, land was less intensively cultivated and in some cases even abandoned in because once dependency on remittances has increased, less agricultural production remained. The addition of capital from migration is considered to inflate land prices, driving the commoditization of land and decreasing the capacity of the poor to access land. In other word, remittances stimulate agricultural land accumulation which leads to changes in the agrarian structure, the system of tenancy and land management. Agriculture and lands were used to be the basis for sustainable livelihoods in Southeast Asia (Kelly 2011), even where access to land is relatively not viewed as the best way for raising rural incomes (Rigg and Vandergeest 2012). Agricultural land is longer doubt to be the most crucial livelihood resource in rural areas of Vietnam. Since Mai Thôn is a predominantly agricultural village, land has traditionally been the foundation of the household economy. This distribution of land to individual producers did not mean that households had ownership of the land. According to the Law, all land belongs to the people of Vietnam and households were awarded usufruct (use) rights to the land allocated to them. Until 1993, when the Land Law was promulgated, households officially did not have the right to transfer these land use rights. In reality, however, farmers wanted and did "buy and sell land use rights, transfer them to their heirs, lend them to other people and use them as collateral" (Kerkvliet 2006: 295). Under the 1993 Land Law this practice became officially authorised. The law not only guaranteed the allocation of farmland for long and stable use but also stipulated (article 3, paragraph 2) that: "Households and individuals have [the] right to exchange, transfer, lease, inherit and mortgage land use rights" (Quốc hội Nước Cộng hòa Xã hội Chủ nghĩa Việt Nam 1993) land. Under the revised Land Law of 2003, land became recognised as "a special good, having a value and hence able to be traded" (Phan Vu Quynh Chi and Fujimoto 2011: 173). Therefore, under the revised Land Law that came into force in July 2014, the land use rights for Vietnamese farmers have been extended for another 50 years - thus offering farmers a long-term perspective on the market for land use rights.

Following the promulgation of the Land Law in 1993 and the Government decree number 64-CP on the redistribution of lands to peasant households, Maithon commune also started the process of land distribution early in 1992 and completed in 1993. The logic of the land reforms and (re)distributions of 1993 was to return land to the basic unit of production: the household support implementation of the Household Contract Responsibility System Policy. The agricultural land was divided equally among village residents who was born before 1992, named "dinh muc" (Note 3). Not all land within a commune was allocated. Five percent of land was kept "to defray public expenses or readjust land allocation periodically to demographic changes such as family members returning from military service" (Chung, 1994, p. 4). Other land such as ponds, lakes and garden areas, which are difficult to divide, were often also left unallocated, and then assigned to individual households on the basis of competitive bidding. Land was basically distributed as follows: each « dinh muc » was entitled to receive several small plots of land some of which would be fertile crop land while others of low quality; and some plots of land would be close to the residential areas while others were situated in more distant locations. 
At that time, the whole village had 531,5 "dinh muc". One "dinh muc" was divided 1 sao (Note 4) 12 thuoc (Note 5), later in 2007-2008 when implementing land consolidation, each "dinh muc" was divided again 1 sao 5 thuoc, which equivalent around $470 \mathrm{~m} 2$. Due to the type of agricultural land in the area is relatively diversified as presented, Mai Thon village households are also divided fairly diverse kinds of lands, often include: residential place (home + garden + pond); agricultural land and alluvium land (Note 6). The aim of this distribution was to ensure that all households felt they had been treated in an equal manner in the allocation of agricultural lands. The disadvantage, however, was that the lands distributed to individual households were often too small and fragmented for efficient agricultural production.

Therefore, in 1997, the General Directorate of Land Survey organised a conference on land reallocation to solve the problem of fragmentation of agricultural plots. The outcome of this was the reallocation of agricultural land with the aim of reducing the number of plots owned by a household. In Maithon, agricultural land reallocation followed the directives, resolutions, plans, and projects as issued by the provincial level to the district and commune levels. Reallocation was implemented through the "Project of transforming small plots of lands into larger plots of lands in order to change the economic structure for carrying out industrialization and modernization of rural areas." (Uỷ ban Nhân dân xã Chi Lang 2001a: 1-6) This process of reallocation extended over four months, from August to November 2009. The rules for reallocation were that each household was to retain the same area of land as before, while the number of plots should not exceed three parcels, in three locations, and of three land ranks. Therefore, overall Maithon village shares the same characteristics with other Red River Delta province that the wealth diferentiation of rural households doesn't depend on their landholding size because the great majority of households have only small plots of about 1,000-3,000 square meters per household, and as a matter of fact, most of people “don't make a fortune from farming activities” (Bùi Quang Dũng \& Đặng hị Việt Phương 2011: 14). As T. Rambo and T.C. Le commented, "(Red River Delta) farmers will not get rich from these lands, but at least they are guaranteed a source of livelihood that more or less adequately provides for their family's sustenance."

Before the implementation of land consolidation in 2009, each household usually had over a dozen plots of agricultural land. However, after successful land consolidation, the number of these plots for each household was considerably reduced. On paper, each household usually has 4 plots, according to four round split: low field, high field, plated field and vegetable ground. However, the village cadre emphasized that they are only the numbers on paper to withdraw the Vietnamese Government funding for land consolidation. Village households could exchange land between themselves, although this did need to be approved by the commune officials. These additional mechanisms allowed households some flexibility in coming to joint arrangements, which proved to be particularly attractive among relatives, so that each household has about 2-3 agricultural plots of land. Recently the arable lands on which villagers could be broken down as follows:

Total area of arable lands: $52 \mathrm{ha}$

Area of rice fields: $30 \mathrm{ha}$

Aquaculture surface: $15 \mathrm{ha}$

Area of other cultivable lands: 7 ha

According to a land survey carried out in Mai Thon in 2015 has a surface area of 52 hectares. The agricultural land area are used mainly to cultivate wet-rice $(30 \mathrm{ha})$. Besides growing two harvests of wet-rice per year, some of these areas are also used for extra subsidiary vegetable crops. There are 15 ha used for aquaculture production. Currently, land 15 ha ponds managed by 5 households, used to raise fish, ducks, fruit growing and pig farming. There are also 7 ha of alluvium/inning land by the Duong River. Regarding housing and gardening, the residential areas occupy $13 \mathrm{ha}$, whereas areas for gardening are 5 ha.

Table 1. Mean of agricultural land among Maithon households

\begin{tabular}{llllll}
\hline Indicators & $\begin{array}{l}\text { Group 1 } \\
(\mathrm{n}=42)\end{array}$ & $\begin{array}{l}\text { Group 2 } \\
(\mathrm{n}=23)\end{array}$ & $\begin{array}{l}\text { Group 3 } \\
(\mathrm{n}=42)\end{array}$ & $\begin{array}{l}\text { Group 4 } \\
(\mathrm{n}=15)\end{array}$ & $\begin{array}{l}\text { Total } \\
(\mathrm{n}=122)\end{array}$ \\
\hline Agricultural land $\left(1993\right.$, mean, $\left.\mathrm{m}^{2}\right)$ & 1706.4 & 1931.3 & 1632.5 & 2169.0 & 1859.1 \\
Agricultural land $\left(2014\right.$, mean, $\left.\mathrm{m}^{2}\right)$ & 1724.6 & 1763.8 & 1543.6 & 2350.0 & 1808.8 \\
\hline
\end{tabular}

Source: Household survey 2015

Table 1 showed there were only very small exchanges among villagers and land conversion for commune purposes since the agricultural land market is not well developed in Vietnam in general and in Bac Ninh in 
particular. Overall, the farm households cannot sustain their livelihoods with small land areas therefore they had to find an off-farm job and outside the village. However, the overall trend was observed that most of the group maintain their own agricultural land, except for the slight decrease of group 2 and increase of group 4 in landholdings in comparison between the year 1993 - the moment of land redistribution in Vietnam and in 2015. Without migrating members, this group of non-migration households were likely to rent more land of the migration households in the village or commune to expand agricultural production. However, it should be notice that they rarely expand their agricultural production into large scale farm. Wet rice production in Vietnam requires considerable labour input, especially during transplanting and harvesting. Therefore, literature reported that the movement of people from farm to non-farm employment and from rural to urban areas typically causes agricultural labour shortages, and forces farmers to adapt their farming techniques. In the Southern of Vietnam (Mekong River Delta), farmers have mechanized rice production (Hoang Xuan Thanh et al. 2013). However, in the Red River Delta, the household division of labour and production process will easily adapt to the out-migration of one or two members, and to the subsequent relative labour shortage and decreased flexibility in production sphere.

According to the Land Law, the land needs to be re-allocated in consistence with the demographic changes after 20 years. Therefore, the agricultural land in Maithon was rellocated in 2013, but all the villagers agreed to keep the agricultural land to stay the same. Besides, the duration of land assignment and recognition of agricultural land use rights for households and individuals directly engaged in agricultural production shall comply with the provisions of Clauses 1 and 2, Point b of Clause 3, Clause 4, and Clause 5, of Article 129, Land Law 2013 is 50 years. Following the Law, peasants have the usufruct of the land and there would be no change in the 50 years' land tenure period.

\subsection{Main Features of Correspondent Households}

Even though the industrialization process started in Bac Ninh province since 2001 with the large agricultural land acquisition to build up the industrial zones, Mai Thon village totally stood out of this movement. However, associated with the rise of industrialized zones nearby, the village's agricultural labors have opened the chances to find an extra non-farm jobs. This dramatically effected on the changes in labor structure of farm households. Table 1 described the main characteristics of surveyed households in which demographic features of households are focused, includes household/family size; labour size, migration labour size. Household size indicates how big a family is - it is a unit of measurement used to show the number of members living in a family, consisting of parents, children and others. Household size depends on couples' birth rate and model of different generations living together in a family. In traditional Vietnam agricultural society, a big number of offspring is a symbol of a prosperous family, and satisfied a big amount of manual labor was needed, which resulted in a high birth rate and big household size. Also, many Vietnamese generations lived under the same roof. Whereas in the process of industrialization in recent years Vietnam, the birth rate is low and grown up children do not live with their parents, so the household size is smaller (Bergstedt 2012). The household size of Vietnam decreased from 5.22 persons per household in 1979 to 4.48 persons per household in 1989, 4.61 persons per household in 1999 and this number was 3.8 in 2009, declining by 0.81 person compared with 1999 .

Table 2. The socio-economic charateristics of survey households

\begin{tabular}{llllll}
\hline Indicators & $\begin{array}{l}\text { Group 1 } \\
(\mathrm{n}=42)\end{array}$ & $\begin{array}{l}\text { Group 2 } \\
(\mathrm{n}=23)\end{array}$ & $\begin{array}{l}\text { Group 3 } \\
(\mathrm{n}=42)\end{array}$ & $\begin{array}{l}\text { Group 4 } \\
(\mathrm{n}=15)\end{array}$ & $\begin{array}{l}\text { Total } \\
(\mathrm{n}=122)\end{array}$ \\
\hline Household labour & & & & & \\
\hline Family size (mean, pers.) & 4.8 & 5.1 & 4.6 & 4.3 & 4.6 \\
Labour size (Note 7) (mean, pers.) & 2.7 & 2.8 & 2.8 & 2.6 & 2.5 \\
Male labour (mean, pers.) & 1.4 & 1.5 & 1.4 & 1.2 & 1.3 \\
Female labour (mean, pers.) & 1.3 & 1.3 & 1.4 & 1.4 & 1.2 \\
\hline Migration labour & & & & & \\
\hline Mean, pers. & 1.8 & 1.9 & 2.3 & 0 & 1.5 \\
Number of migrants (pers.) & 76 & 43 & 98 & 0 & 219 \\
Male migration labor (Note 8) (mean, & 0.9 & 1.0 & 1.1 & 0 & 0.8 \\
pers.) & & & & & \\
Female migration labour (mean, pers.) & 0.8 & 0.9 & 1.2 & 0 & 0.7 \\
\hline
\end{tabular}

Source: household survey 2015 
Table 2 shows that the average family size of Maithon household is 4.6 people which is higher than the average family size of Red River Delta (3.79); rural areas region (3.9) and the national (3.8) according to the 2009 Vietnam population and housing census conducted on April 1st 2009. It goes with the claim that Bacninh is the highest density population city in Red River Delta and in Vietnam. This mainly due to the families in Maithon keep living three or more generations under the same roof rather than the high birth rate. Among four groups, the smallest households size is the non-migrant (4.3) while the largest one is the family who pursuit migration for long distance (5.1). While the labour size of the three migration household groups are relatively equal $(2.7 ; 2.8$ and 2.8), the migration size of the research groups are quite different, in which the migration labour of the group 3 is highest 2.3 person per household.

\subsection{Impact of Migration over Land Use Purpose for Agricultural Activities}

During 20 years of Doi moi, land tenure Maithon have witnessed remarkable change. It is worth to remind at the beginning that lands throughout the country are under the "whole-people ownership" (sở hũu toàn dân) statute, and agricultural households possess only land-use right instead of land-ownership right. According to article 129 of the Land Contract Law, the right to use the land may be circulated by subcontracting, leasing, exchanging, transferring or other means. Especially, the peasants have to return land to the state for public interests, such as the construction of highways, water conservation facilities and national defence projects. Selling or converting agricultural land to other purpose is strictly restricted according to the related regulations.

Even though being the smallest province of the Red River Delta of Vietnam, BacNinh province has been considered as prominent in term of industrial development in Vietnam. At the time of its formation in 1997, Bacninh was an agricultural province, with only several handicraft villages and no industrial zone or industrial cluster. Since 1998 the provincial government started acquiring agricultural land for industrial purposes, after which the first industrial zone has been built. To date, BacNinh has 15 industrial zones and more than 35 industrial clusters with more than 9400 ha agricultural land acquired (Note 9). This encouraged many rural households to sell their agricultural land use right. The average level of compensation for one sào of agricultural land in 2000 was 30 million VNĐ, it doubles in 2007, including four items of compensation and assistance. This rapid increase in land price compensation had changed some farmers become millionaires overnight. However, in sharp contrast to the land boom in BacNinh itself, this did not occur in Mai Thon. Located in Que Vo district which has the largest industrial zones within the province with 1,204 ha already converted for industrial zones, Mai Thon villagers in contrast with other villages in the same district, have no conversion of land for other purpose than another agricultural activities.

Table 3 showed that $84.4 \%$ of the respondent households keep their land for agricultural production. Among migrating groups, the households only participated in commuting devoted their land for farming activities at the highest proportion (90.5\%) which is coherent with the analysis about migration types in part 4 . It is also interesting when we notice that majority of daily-shift migrants are female who turn out still the main people taking care of their family farming. When female labors migrate, they tend to find the job not too far from their villages so that they can manage to do the agricultural works, especially during the peak time. Besides, the Vietnamese gender norms consider housework is the female task and the bread earner is the men. Therefore, in the Vietnamese feudalism when agriculture is the main earning source, the main participation of male in farming could be observed. However, recently even when agriculture is no longer the main source of household income, farming gradually becomes the female's extended housework responsibilities. It results that when women migrate and the men as the left behind members, women also need support the men and work together with the men. As the result, the female migration seems to have the positive impacts on agricultural land use for agricultural production. Table 2 showed that while none households in the village absolutely leave their farming land fallowed, there were 6.3 households partially abandoned their land. However, this usage of agricultural land in Mai Thon is more potent than other village in Chi Lang commune, for example Que O has already abandoned a few acres (Chi Lang Commune reported, 2014).

Following the land division round, most of households has approximately one third of their paddy field in high quality which could be used to grow two seasons of rice and one winter season of vegetable and/or other cash crops. However, in $2015,90 \%$ of Maithon households recently abandon this vegetable winter seasons. In term of rice production, there are some households who grows only one season in order to keep their land, because the 2013 Land Law claimed if the peasant does not cultivate in their land for continuous two seasons, they would be withdrawal the land to the public. This is considered as the main reason forced the peasant household manage to keep agricultural production on their land by multiple ways including: partially abandon, partially leasing, partially lending, and partially producing while they are pursuing other non-farm business or migrating. The case of Mr Huong illustrated for their diversified pathways in maintaining agricultural land 
Mr Huong household has 5 members, including his mother, his wife and two children which were all born before 1993 - the land distribution time. The agricultural land that his family was distributed 5.2 sao (Note 10) combined with 2.6 sao he was inherited from his parents, so their total farming land area was 7.8 sao. He has been a construction worker for ten years, therefore he normally spent twenty days per months commuting around village for work. When their children were small, his wife took care of their children and they were farming together with high capacity. They grew two rice seasons and one vegetable season in winter in one sao of high quality land. In 2018, his wife followed her sister migrating to Hanoi to be house cleaner, his agricultural land witnessed a dramatically change. Firstly his family totally dropped growing vegetable. And then, he lended one third of their land (3 sao) for his brother-in-law to grow rice. Recently he rented 2 sao to Mr Phuc to grow potatoes. Therefore his family now are only really take care of 2.8 sao and they only grow high quality rice for their family consumption. The year before he had an work accident therefore now Mr Huong mostly stay at home and responsibility for farming daily care His wife will come back home for transparenting and harvesting. His first son, Mr Hoang is 31 years old and he has opened one hairdresser shop with his wife in Pho Moi town-near Bacninh city for 3 years after few years working in the Que Vo Industrialized zones. Mr Huong's son and his wife lives in their clothes shop but their 3 year-old-child is now living in Maithon village with Mr Huong. They normally come back home with their child at the weekend. Mr Hoang intended to let his wife take care of the shop herself and he will come back home takes charge of farming and his sick farther. He stated if he did that, he would take back all their paddy field.

Mr Huong case shows that agricultural land assure people a job, a livelihood and somehow it is like a backup strategy. Whatever they do outside, if they fail they can always go back to their own land. Li (1996) pointed out that Vietnamese migrants maintain their agricultural land use right as an insurance for their life because of the fear of unstable jobs in the cities as well. The agricultural land is not only the livelihood for themselves but also for their children in any circumstances. Therefore Mr Huong lend the land for his-brother-in-law for free. He even need to support his brother-in-law pay the agricultural service for the Chi Lang commune (which would be around 200000 vnd per year) so that the agricultural land makes sure belong to his family. Keeping the agricultural is always the priority of Maithon peasants. Devoting the agricultural land for the agiruclture would ensure food security (both in quantity and quality) for their families. The quality of home food becomes very important recently when food safety is warning in Vietnam. home produced food is also considered as everyday practices of rural household to ensure their food quality (Nguyen Thi Minh Khue, Nguyen Thi Dien, and Ph. 2016b). Reflecting on his research in rural Thailand, Vandergeest (2012:154) argues that maintain land and agrarian activities provide higher incomes and better health than unskilled wage labour among those who could be the most marginalized (Vandergeest 2012). Likewise, in Laos most poor rural households, daily basic food requirements were commonly met by subsistence farming, since most of them own farmland (Sothichack, 2013).

Table 3. Migration and agricultural land use

\begin{tabular}{lcccccccccc}
\hline $\begin{array}{l}\text { Agricultural land } \\
\text { use (Unit: } \text { hhs })\end{array}$ & \multicolumn{2}{c}{$\begin{array}{c}\text { Group 1 } \\
(\mathrm{n}=42)\end{array}$} & \multicolumn{2}{c}{$\begin{array}{c}\text { Group 2 } \\
(\mathrm{n}=23)\end{array}$} & \multicolumn{2}{c}{$\begin{array}{c}\text { Group 3 } \\
(\mathrm{n}=42)\end{array}$} & \multicolumn{2}{c}{$\begin{array}{c}\text { Group 4 } \\
(\mathrm{n}=15)\end{array}$} & \multicolumn{2}{c}{ Total (N=122) } \\
\cline { 2 - 12 } & $\mathrm{N}$ & $\%$ & $\mathrm{~N}$ & $\%$ & $\mathrm{~N}$ & $\%$ & $\mathrm{~N}$ & $\%$ & $\mathrm{~N}$ & $\%$ \\
\hline $\begin{array}{l}\text { Agricultural } \\
\text { production }\end{array}$ & 38 & 90.5 & 17 & 73.9 & 35 & 83.3 & 14 & 93.3 & 103 & 84.4 \\
$\begin{array}{l}\text { Land converted } \\
\text { Land partial }\end{array}$ & 1 & 2.4 & 0 & 0 & 1 & 2.4 & 1 & 4.7 & 3 & 2.4 \\
abondant & 1 & 2.4 & 2 & 8.7 & 5 & 11.9 & 0 & 0 & 8 & 6.3 \\
\hline
\end{tabular}

Source : Household survey 2015

Moreover, although households with migrant members usually keep practicing agriculture at very limited level, in most cases, agricultural land on one hand can ensure the food subsistence of the family remained in the village. Besides, the priority in holding land also implies their villager waitting for some extraordinary value if there would be land conversion. The case of Mr Huong also illustrates how villagers engage in land exchange transactions in order to make up for the imbalances between labour and land within and between households, which have become even more pronounced as a result of labour migration. It is to this point that we now turn. It's noteworthy that first even though agricultural land market is strictly forbidden in the Red River Delta, the underground exchange is 
happening. In the peasants' everyday language continue to talk of "selling lands" or "purchasing lands" instead of "transferring land-use right" as legally and officially specified. However, the most of the transation happened in the rental and the most important reasons leading to the practice of land rental are changes in the size and nature of the household labour force.

\subsection{Agricultural Land Exchange Transition}

As noted above, in 1992 and 1993, each household in Maithon was allocated an area of agricultural land for a period of 20 years depending on the number of people living in the household. Under the new Land Law, which came into effect as of July 2013, this period will be extended to 50 years. During the reallocation in 2009, the division of plots changed, but not the size of land allocated to each household. However, between the original land allocation in 1992 and the reallocation in 2009, the number of people living in each household had changed, sometimes quite dramatically, and this altered the use of land and the organisation of agricultural production in the village. In some households, there were more people of working age because household members had married and their spouses were living with the household, or children had simply become adults in the intervening years. In other households, the number of household members had increased because of the birth of new household members. Conversely, ageing and death had reduced the number of working age adults, or migration had taken them out of the household labour force even if they were still regarded as household members. These demographic perturbations led to an unsettling of the balance between land and available labour, which in turn has driven the land rental market. We see this illustrated through the case of Mr Manh:

Mr Manh was born in 1974 and graduated from high school in 1991 before proceeding to agricultural vocational school. However, he was not able to secure a job with this diploma so he stayed home to work as a peasant. His wife comes from BacNinh city. They have two children, aged six and two. They all live with Mr Manh's mother, who is widowed. Mr Manh and his wife have five sào of agricultural land. This is the field share allocated to him and his parents in 1993. His wife moved to live with Mr Thäo after the village's agricultural land had been allocated, so she did not receive a field share. His two children were also born after the time of land allocation in Maithon, so they also have no field shares. In addition to the field shares, Mr Manh's household rents four sào of agricultural land from two other households in the village, Ms Nam's and Mr Hồng's. Ms Nam is 71 years and she was sick for long time. Her husband died a long time ago and she lived with the first son. She has four children. Among them, her three adult children have migrated and settled down in other city. Herhousehold has seven sào of agricultural land but cultivates only three sào to produce enough rice for the household's consumption. The rest of his household's field shares have been let out to other households including Mr Manh's. Since 2008, Mr Manh has rented 1.8 sào of rice land from Ms Nam. At that time, Mr Manh visited Ms Nam and asked whether he could rent some of his land. Ms Nam agreed. In return Mr Manh pays $70 \mathrm{~kg}$ of rice per sào, which he takes to Mr Manh's house as payment following harvest. This transaction is based on a verbal agreement between the two parties.

The example of Mr Manh illustrates the changes in land-to-labour ratios since the original land distribution and how this is driving the rental land market in the village. Ms Nam is old and have largely withdrawn from work; in addition, their children have left the village to work in other localities. Ms Nam's household have, as a result, insufficient labour to cultivate the land allocated to them. They therefore only retain a portion of their total field area to cultivate. The rest they let out to others who are in labour deficit, such as Mr Manh's household. Mr Manh's household is comparatively young. His children and his wife did not receive shares of agricultural land at the time of the distribution and they therefore have to resort to renting agricultural land from Mr Vinh and Ms Nam to be able to meet their subsistence needs and derive an income. The fact that Mr Manh's household has dependent children also limits their scope for migration. This practice of letting land shows that demographic changes and out-migration do not necessarily lead to de-agrarianisation or fallow lands, as some scholars (Rigg 2001 and 2006; Rigg and Nattapoolwat 2001) have predicted, but rather to arrangements that shift the use of agricultural land from labour-deficient households to labour-rich households. The remittances from migrant household members partially release those left behind from farm work. Instead of leaving the land fallow, rental arrangements allow young households that have enough labour but lack land to farm extra land to provide for their families. This also has implications for how land use is linked to prosperity: cultivating large areas of rice land is not necessarily a sign of being well off, but more likely a labour use and allocation strategy.

Table 4 reveals the land exchange activities in Maithon village, in which renting and lending are far more popular than land sale. Villagers are unlikely to sell their land $(0.8 \%)$, but rather leasing $(10.7 \%)$ and lending $(18 \%)$ or even leaving it fallow for certain crop as discussed before. The case of Ms Nga illustrates for the complex picture of land holdings fluatuation in rural households, which was a remarkable influenced by the family members' migration. 
Based on the 1992 land allocation exercise, Ms Nga and her husband were each allocated 2.6 sào of land. One plot (0.6 sao) she was allocated was far away from the village and close to the river. Since it was not very convenient to work this plot because her children were small and her husband migrated to Hanoi for work, she rented out the land to Mr Lam, who paid her a fixed rent of $30 \mathrm{~kg}$ of paddy per year. In turn, Ms Nga lent two sào from her mother in law, who was old and, after Nga's father in law had died, no longer needed her land. When her children were young, four sào were enough to grow rice for her family. When there were numerous households in the village left paddy field to go to Ho Chi Minh city in 1998, Ms Nga rented two additional sào from Ms Van, to whom she pays a rent of $60 \mathrm{~kg}$ of paddy per year. In other words, during the 2000s Ms Nga now works six sào of paddy field, of which only two sào is owned by the household. Recently, Ms Nga followed her cousin to worked in Hanoi, she rented out 3 sao for Mr Phuc to grow potato. To complicate things further, Mr Lam has sublet Ms $\mathrm{Nga}$ 's plot of land to a villager in a neighbouring village, Thon Dong village now.

Table 4. Land exchange transaction in Mai Thon village

\begin{tabular}{lrrrrrrrrrr}
\hline \multirow{2}{*}{ Land use pattern } & \multicolumn{3}{c}{ Group 1 $(\mathrm{n}=42)$} & \multicolumn{2}{c}{$\begin{array}{c}\text { Group 2 } \\
(\mathrm{n}=23)\end{array}$} & \multicolumn{2}{c}{$\begin{array}{c}\text { Group 3 } \\
(\mathrm{n}=42)\end{array}$} & \multicolumn{2}{c}{$\begin{array}{c}\text { Group 4 } \\
(\mathrm{n}=15)\end{array}$} & \multicolumn{2}{c}{$\begin{array}{c}\text { Total } \\
(\mathrm{N}=122)\end{array}$} \\
\cline { 2 - 11 } & $\mathrm{N}$ & $\%$ & $\mathrm{~N}$ & $\%$ & $\mathrm{~N}$ & $\%$ & $\mathrm{~N}$ & $\%$ & $\mathrm{~N}$ & $\%$ \\
\hline Rent- out & 3 & 7.1 & 3 & 13.0 & 7 & 16.7 & 0 & 0 & 13 & 10.7 \\
Ren-in & 3 & 7.1 & 3 & 13.0 & 3 & 7.1 & 2 & 13.3 & 11 & 9.0 \\
Lend-out & 2 & 4.7 & 5 & 21.7 & 15 & 35.7 & 0 & 0 & 22 & 18.0 \\
Lend-in & 3 & 7.1 & 4 & 17.4 & 2 & 4.7 & 7 & 46.7 & 16 & 13.1 \\
Sell & 1 & 2.4 & 0 & 0 & 0 & 0 & 0 & 0 & 1 & 0.8 \\
Buy & 0 & 0 & 1 & 4.3 & 0 & 0 & 0 & 0 & 1 & 0.8 \\
\hline
\end{tabular}

Source: Household survey, 2015

It could be observed that most land rental agreements were based on fixed-rent tenancy, although the rental fee fluctuated from year to year. The unit used to calculate the price was the number of kilograms of rice per sào per year. In many cases, in order to make the payment, the tenants brought the rice to the lenders' houses after each harvest. In some cases, however, the tenants paid in cash. The rental fee varied in general from $30 \mathrm{~kg}$ to $80 \mathrm{~kg}$ of paddy per sào per year, depending on the quality of the land, the weather conditions and the relationship between the owner and the tenant. It is remarkably blur between renting and lending due to the rice production revenue is so low that the renting fee is sometimes obmitting. Besides, the utmost purpose of both renting and lending agricultural land in Maithon is to keep land, therefore, the renting fee is not the priority. Ms Nga did not paid her mother because she lived with and took care of her mother in law. Ms Nga paid Ms Van 60kg of paddy per sao due to Ms Van's piece of land was high quality while the land Ms Nga rented out to Mr Việt was, on the contrary, of poor quality. Land was not only rented out to fellow villagers, but also to villagers in neighbouring villages, such as Dong village as illustrated in the case of Mr Lam subletting Ms Nga's riverside plot. As the villager explained, neighbouring Dong village differs from Mai Thon as its inhabitants are relatively poor, and they are not migrating-out to supplement their village incomes thus they prefered to rented land from Maithon villager. Most of the contracts are on verbal and normally valid year by year. And when either the land lenders or the land tenants wish to end their contract, they simply meet and agree to bring the agreement to a conclusion. Ms Nga case also illustrated the enhance of migration on imbalance between labour and agricultural land.

Table 4 also pointed out that the group 4 of non-migration households has the highest proportion in lending in field land for expanding farming (46.7\%), meanwhile they didnot rent-out or lent-out any piece of land. On the other hand, migrating household groups also kept their own land and the maintenance of land rights is always their priority therefore, most of households lease out their paddy field for their brothers, cousins. Among migration households, the group 3 experienced the highest proportion both of lent-out $(35.7 \%)$ and rent-out $(16.7 \%)$ while the group 1 was the lowest category in lend-out (4.7\%) and rent-out (7.1\%). It is interesting to witness the change in land transaction only over the five years of my rearch here. In 2016 when I come back for data updated and gathering more information on youth opinion in agriculture, it is such a amazing that case study of Mr Phuc has consolated 10ha of paddy field under the support of Chi Lang Government officiers. These officer state it followed the New Land Law 2013 application permits rural households change their rice fields into cash crop production 
and the promotion of the Large Field Program. Even though the contract is only year by year but it shows an important remark in land consolidation. In opposite with this mainstream, there is special case of Ms Trac who refuses lending out her land and continues grows vegetable for sale frequently.

Ms Trac was a Mao villager, married to Maithon village since 1983, therefore she was divided agricultural land as Maithon people. Her household has 3 people, her husband is sick and mostly stays at home. Her son worked for the Canon firms in Que Vo IZs, however, he was fired due to gambling and now he is unemployed and vagabond. She therefore became the breadwinner of her family. She cultivated 8 sao for rice production and 2 sao for growing vegetable. Rice is grown for 2 seasons per year while vegetable is grown around the year including: corn, cucumber, tomatoes, chilies...depending on weather and market. The first interesting point is she was the only villager who keeps growing vegetable in small-scale for sale. The second point to notice that her plot of land for vegetable growing was located in the middle of the large farm Nguyen Van Phuc. Mrs Trac had rented this land piece for Mr Phuc in two year (2015 and 2016). However, in 2017, she drew her land back to cultivate on her own, even though she is persuaded by many people to rent it out. She explained that she was cleaner in the companies in the industrialize zones however, the job is unstable and low income, therefore she needs the back-up from farming. Besides, she prefers self-cultivation on her land rather than renting it out because it permits her to be independent in daily consuming and sale. She would be busier but Mrs Trac also works for Mr Phuc if he needed labour in the peak time. She is the case of daily-shift migrant who struggled with the informal work, therefore agricultural land and agricultural activities becomes the best gridlock.

$\mathrm{Mr}$ Trac case on one hand shows the instability of rent land contract among villager. The land arrangements between migrant and non-migrant are informal and temporary in nature. By renting out land, migrant households do not give up their land use rights. They keep their connections with the land and the village and, in many cases, by receiving a share of the harvest, continue to eat rice cultivated on their land. Land remains an important source of security to hold onto in case of return regardless of preference or forcing. The time contract which is year by year, from the Government perspective, it is considered as the constraints for land consolidations, large-scale farm and rural development. However, from the peasant view, short time contract is a security for themselves. Whenever they face with the difficulties in migration process, they would return to their own land and their original livelihood. In other words, it protects their resilience and to some extent strengthen their own autonomy.

\section{Conclusion}

Agriculture and lands were used to be the basis for sustainable livelihoods in Southeast Asia (Kelly, 2011), even where access to land is relatively not viewed as the best way for raising rural incomes (Rigg and Vandergeest 2012). Agricultural land is longer doubt to be the most crucial livelihood resource in rural areas of Vietnam. Since Maithôn is a predominantly agricultural village, land has traditionally been the foundation of the household economy. Majority of households keeps their paddy field and continue their agricultural production rather than converted it into other purposes. While none households in the village absolutely leave their farming land fallowed, there were some households partially abandon their land. Because the 2013 Land Law claimed if the peasant does not cultivate in their land for continuous two seasons, they would be withdrawal the land to the public. This is considered as the main reason forced the peasant household manage to keep agricultural production on their land by multiple ways including: partially abandon, partially leasing, partially lending, and partially producing while they are pursuing other non-farm business or migrating. It's noteworthy that first even though agricultural land market is strictly forbidden in the Red River Delta, the underground exchange is happening. In the peasants" everyday language continue to talk of "selling lands" or "purchasing lands" instead of "transferring land-use right" as legally and officially specified. Renting and exchange agricultural land are much more common than selling. Unofficial re-distribute land among households which have different labour capitals.

It is remarkably blur between renting and lending due to the rice production revenue is so low that the renting fee is sometimes omitting. Besides, the utmost purpose of both renting and lending agricultural land in Maithon is to keep land, therefore, the renting fee is not the priority. It implies that possessing to land is more for investment than agricultural production. In comparison to male migration, the female migration has the positive impacts on agricultural land use for agricultural production because the gender choices related to the pattern of migration allow female migrants combining the migrating job and agricultural production. Non-migration households has the highest proportion in lending in field land for expanding farming, meanwhile they did not rent-out or lend-out any piece of land. On the other hand, migrating household groups also kept their own land and the maintenance of land rights is always their priority therefore, most of households lease out their paddy field for their brothers, cousins. Among migration households, the group households have multiple type of migration experienced the highest proportion both of lend-out and rent-out while the group of daily-shift migration was the 
lowest category in lend-out and rent-out. There is also a dramatically change in land consolidation with an example case of $10 \mathrm{ha}$ farm for growing potatoes and carrot. However, it is noteworthy that, against the mainstream of land consolidation, the year by year contract in land transaction is security for Maithon villager whenever they had constraints in migration. Agricultural land and farm work are always a stable resource, a guarantee of subsistence or a safety net for rural people which would boosting their own autonomy.

\section{Acknowledgement}

Authors wish to thanks the ARES-CCD (Academie de Recherché et d'Enseignement Superieur) for sponsoring this study.

\section{References}

Anh, D. N. (2008). Labour migration from Viet Nam: Issues of policy and practice. International Labour Organization.

Bergstedt, C. (2012). The Lie of the Land - Gender, Farm Work, and Land in a Rural Vietnamese Village. Social Anthropology School of Global Studies, University of Gothenburg, Gothenburg, Sweden.

Minh, B., Nga, B. Q., \& Phuong, D. T. V. (2012). Agricultural land, peasant and rural development. Sociology, 3(119), 26-33.

Coxhead, I., Nguyen, V. C., \& Linh, H. V. (2015). Migration in Vietnam: New Evidence from Recent Surveys. World Bank. https://doi.org/10.2139/ssrn.2752834

de Brauw, A. (2010). Seasonal migration and agricultural production in Vietnam. The Journal of Development Studies, 46(1), 114-126. https://doi.org/10.1080/00220380903197986

GSO. (2011). Migration and Urbanization in Vietnam: Patterns, Trends and Differentials. Hanoi: GSO.

Hirsch, P. (2011). Afterward: re-agrarianisation or repositioning agrarian. In C. Wittayapak \& C. Vaddhanaphuti (Eds.), Revisiting agrarian transformation in the greater mekong subregion: new challenges (pp. 185-188). Chiang Mai: RCSD.

Thanh, H. X., Anh, T. T., Quang, L. T., Giang, D. T., \& Phuong, D. T. T. (2013). Food security in the context of Vietnam's rural-urban linkages and climate change. London, UK: International Institute for Environment and Development.

Kelly, P. F. (2011). Introduction: Migration, Agrarian transition and Rural Change in Southeast Asia. Critical Asian Studies, 43(4), 479-506. https://doi.org/10.1080/14672715.2011.623516

McKay, D. (2005). Reading remittance landscapes: Female migration and agricultural transition in the $\begin{array}{llll}\text { Philippines. Danish Journal of Geography, } & \text { 105(1), }\end{array}$ https://doi.org/10.1080/00167223.2005.10649529

Dien, N. T., Lebailly, P., \& Vu, D.T. (2014). Agricultural land conversion for industrialization: Livelihood along rural-urban continuum and mechanism of social differentiation in Hung Yen province, Vietnam. In Lebailly Ph., J. Ph. Peemans \& Vu D. T. (Eds.), Rural development and small farmers in South East Asia: lessons of experiences in Vietnam and Cambodia. GRAESE: Groupe de Recherches Asie de l'Est et du Sud-Est.

Khue, N. T. M., Dien, N. T., \& Lebailly, P. (2016a). Agricultural Production in the context of Industrialization and Food Security in Vietnam. AGROFOR International Journal, 1(1), 86-94. https://doi.org/10.7251/AGRENG1601086N

Khue, N. T. M., Dien, N. T., \& Lebailly, P. (2016b). Agricultural Production in the context of Industrialization and Food Security in Vietnam. In VII Scientific Agriculture Symposium "Agrosym 2016". Bosnia and Herzegovina.

Phuong, N. T., Tam, T. N. T. M., Nguyet, N. T., \& Oostendorp, R. (2008). Determinant and Impact of Migration in Vietnam. In Working Paper Series No. 2008/01, edited by The DEPOCEN working paper series. Amsterdam.

Peemans, J. P. (2013). A political economy of rural development in South East Asia in relation with the many versions of the disappearance of the peasantry. Louvain la Neuve: Centre d'Etudes du Développement, UCL.

Rigg, J. (2005). Poverty and livelihood after full-time farming:a South-East Asian view. Asia Pacific Viewpoint, 46(2), 173-184. https://doi.org/10.1111/j.1467-8373.2005.00266.x 
Rigg, J., \& Vandergeest, P. (2012). The restudy "problem" and agrarian change: revisiting rural places in Southeast Asia. In J. Vandergeest Rigg (Eds.), Revisiting rural places: pathways to poverty and prosperity in southeast Asia (pp. 1-24). Hawaii: University of Hawaii Press.

Rigg, J., \& Nattapoolwat, S. (2001). Embracing the global in Thailand: Activism and pragmatism in an era of de-agrarianization. World Development, 29(6), 945-960. https://doi.org/10.1016/S0305-750X(01)00021-3

Vaddhanaphuti, C., \& Wittayapak, C. (2011). Revisiting Agrarian Transformation in the greater Mekong sub-region: new challenges. Edited by C. \& Wittayapak Vaddhanaphuti, C. Chiang Mai: RCSD.

Vandergeest, P. (2012). Deagrarianization and re-agrarianization: multiple pathways of change on the Sathing Phra peninsula. In J. Vandergeest Rigg (Eds.), Revisiting rural places: pathways to poverty and prosperity in southeast Asia (pp. 135-156). Hawaii: University of Hawaii Press.

\section{Notes}

Note 1. The area of land devoted to production agriculture accounts for $29 \%$ of Vietnam's total land area; Vietnam currently has only 0.11 hectares of agricultural land per person. This area however is distributed uneven distribution across regions. In the Red River Delta, land area for agricultural production accounts for 0.04 hectares per head. IN Mekong Delta, the average MRD people have land for 0.14 hectares agricultural land (Bui Minh 2012).

Note 2. Hokhau is a complex household registration system in Vietnam, which accords residency rights to people. A hokhau refers to a family register in many contexts since the household registration record is issued per family, and usually includes the births, deaths, marriages, divorces, and moves of all members in the family. The agricultural land distribution in Vietnam was conducted based on hokhau system.

Note 3. "dinh muc" was defined as a village member, from young child to the eldest people, 1 person was 1 "dinh muc", except those who already had a pension age at that time were calculated as 0.5 "dinh muc".

Note 4. 'Sào' is the unit of agricultural land which is used popularly used in Vietnam until now. In Northern Vietnam, one sào of agricultural land is about $360 \mathrm{~m}^{2}$. Or one sào $=0.036 \mathrm{ha}$. One household may receive several plots of land depending on the number of people in the household and features and size of the individual paddy field fields.

Note 5. Thuoc is also the unit of agricultural land. In Northern Vietnam, 1 thuoc of agricultural land is about $24 \mathrm{~m}^{2}$ and $1 \mathrm{sao}=15$ thuoc.

Note 6. The inning land was also was allocated to households in 1992, however, latter village households had a meeting and agreed to aggregate this land to lease. At the $1^{\text {st }}$ time this inning land was leased in 1999-2009 to make bricks. Villagers are divided profit according to their land area. At the 2 nd time, inning land has been leased from 2009-2019 for banana planting. The rent is collected to rebuild the dam, field canals and using for land consolidation campaign in 2009.

Note 7. Included migration labour.

Note 8. Migration labour at the research time 2014-2015.

Note 9. The data has been collected at the official website of Bacninh Industrial Zone (http://www.izabacninh.gov.vn/?page=home\&portal=kcnbn accessed on 16 of Feb, 2014) and Decision 396/QĐ-UBND, issued on 31, October 2013 on the approval of the cluster planning in Bacninh province to 2020, vision 2030).

Note 10. Repeat note 4.

\section{Copyrights}

Copyright for this article is retained by the author(s), with first publication rights granted to the journal.

This is an open-access article distributed under the terms and conditions of the Creative Commons Attribution license (http://creativecommons.org/licenses/by/4.0/). 